\section{The Politics of Gender: Women, Education and the Market in 1993}

\author{
ANNE-MARIE O’NEILL
}

\section{Abstract:}

This chapter sets out an analysis of the assumptions underlying the new educational settlement (Grace, 1990). In particular, it analyses the patriarchal nature of the "world view" and practices of that settlement guiding model, that is a free market and its endorsement of what I have termed the concept of rational market man. The intellectual paucity of neo-liberalism free market ideologies and possessive individualism which have guided and legitimated educational change are starkly revealed when a gender analysis is applied to them. This chapter examines a few of the multitude of different "realities" through which women live out their lives in a gendered and unequal society. Such realities are closely related to educational provision and yet they can never be taken account of (and never resourced) in educational policy and planning as long as the hegemony of market models is retained.

\section{Introduction}

The small country of New Zealand offers a cautionary tale. Its recent history provides sobering evidence of the American model's ability to wreak havoc in both the economic and social spheres. Long regarded as one of the world's most enlightened social democracies, New Zealand has, since 1984, demolished a cradle-to-grave social welfare system in the name of economic efficiency. Nevertheless, untrammelled markets have not produced vigorous economic growth. On the contrary, eight years of stringent monetarist policies have produced massive unemployment, rising crime rates, a widening gap between rich and poor, and a declining GDP. Between 1985 and 1990, New Zealand's GNP fell by $0.7 \%$, the worst record of any industrialised country, while unemploy- ment more than doubled. The deterioration in living standards has been particularly severe among families with children, with predictable results. New Zealand now has the highest youth suicide rate among industrialised countries, and reported cases of child abuse have doubled since 1985. (Hewlett, 1993, p.53)

T 993 has been a year of strange juxtapositions. Middle-class women have had a multitude of conferences, books and outings competing for their discretionary incomes in the celebration of women's suffrage. The election campaign, particularly that mounted by the Alliance, foregrounded the social devastation and injustice of the New Right's "decent society" in a way that had never been so sustained before. The election result provided a clear signal to the politicians that the end results of policies driven primarily by economic dogma have affected people, are understood by them, and are no longer tolerated by them. We have had a Minister of Women's Affairs who has advocated the government to women, rather than being an advocate for the rights of women to her government. We have had to contend with a massive campaign of misinformation mounted by the state about the social and economic realities its people live under. Nowhere has this been more obvious than in the contestation of gender relations and sexual politics under New Right social and economic policies. When these are analysed, along with the relations of ethnicity and the politics of racism, the real injustices and inequalities of the free market are starkly revealed. A recent example of the ideological struggles taking place over gender and the legitimation of the state, was the election statement sent out by Jenny Shipley (as Minister of Women's Affairs) to voters on ministerial notepaper. It discussed health, welfare, early childhood and National's "constructive moves to educate, train and get women into the workforce". Apart from providing an indicator as to why our political/ parliamentary processes are held in such disrepute, this mailout is a singular example of why sustained and integrated analyses of gender and ethnicity are so vital to any consideration of the state, its policy rhetoric and most essentially its policy outcomes. ${ }^{1}$ 
Last year in this publication (O'Neill, 1993), I discussed the following: the Draft National Curriculum in relation to its warm and fuzzy gender inclusive rhetoric; the National Certificate which fits into the National Qualifications Framework which could provide formal recognition for the skills, attributes and capabilities that women bring to paid work; the Parents as First Teachers programme which now involves 1,500 families in poorer areas up and down the country, and which has recently been described by the Prime Minister's Office as a crime prevention strategy; the Study Right policy which blatantly discriminates against mature students, the majority of whom are women; the disestablishment of the Girls' and Women's Section in the Ministry of Education; and the Report on Policy Project Phase One. All of the above were discussed in the context of the phenomena of the state's retraction from its rather "inconvenient sense of social responsibility" (Bunkle and Lynch, 1992, p.26) and the concomitant forging of the new educational settlement (Grace, 1990, p.170). These were phenomena which implied massive ideological reconceptualisations of notions of the individual, of education, from that of a public good to a commodity to be bought and sold like any other on the market, to the perception of state educational provision as a destructive rather than a constructive force in our history. These realignments were legitimated by sometimes elaborate and sometimes scant references to "equity", the equality of outcomes or results. Thus far, it is the fiscal imperatives underlying educational change which have dominated this settlement (see Lauder and Wylie, 1990; and Middleton et al., 1990). Against the primacy of an androcentric market model, "equity" concerns, particularly educational outcomes for women and girls (and other nondominant groups) remain subsumed. As I argued in 1993, when placed within the wider contexts of other state policies (which impinge upon, and help shape the educational) it is doubtful as to whether equality of educational opportunity even exists for certain groups of women and the working classes in this country.
Thus recent educational restructuring, current educational policies and policy outcomes for girls and women must be seen against the backdrop of an administration which has consistently attacked the personal, structural and political gains that women have made. In its first term with an official level of $10.3 \%$ unemployment (unofficially in-between $18-20 \%)^{2}$, the National Government repealed the Employment Equity Act, drastically cut welfare benefits and implemented six-month stand downs, introduced the Employment Contracts Act, introduced youth pay rates, cut funding for post-compulsory education for mature students, implemented market rentals for state owned housing, implemented user-pays in the health sector, dismantled labour market protection mechanisms (particularly important for its feminised and youth sectors) and indulged in massive spending sprees to promote its own legislation (see Boston and Dalziel, 1992, for detailed discussions of the above).

The discussion in this chapter builds up on that which was set out in last year's article (O'Neill, 1993) where I analysed the intellectual origins of liberalism and the emergence of what Sharpe (1980) calls "the bourgeois subject" out of the male property-owning classes in the 17 th and 18 th centuries. The conception of rationality that this model embodies was constructed on the naturalness and legitimacy of male attributes, capacities and modes of activity. This model was challenged under Keynesianism as I demonstrated in the analysis of educational policy documents which were based on the premises of liberal welfarism. The ascendancy of the fourth Labour Government in 1984 ushered in the challenge of a revived neoclassical liberalism, re-emphasising the possessive qualities of the classical liberal individual (as the rational-market-man), against the backdrop of the market.

As this chapter argues, rational-market-man (always theoretically dressed in unisex clothes) is very definitely a gendered conception of the individual. Policies and structural changes which embody such assumptions about rationality and capacity and the social world in which they are exercised, are not 
only epistemologically and ontologically flawed, but as Court's (1994) analysis (in this volume) of the educational labour market reveals, they are constitutive of discourses which seek to reproduce and exacerbate the complex divisions of inequality so essential to capitalism. Such assumptions cannot account for people as anything other than self seeking. They cannot acknowledge differing family/whanau resource bases and networks, nor can they acknowledge the real effects of the dominance and subordination underlying capitalist social relations. This is why, as Bunkle (1993, cited in McCulloch and Cleary) has argued, feminist analyses must grapple with the restructuring of the economy and the economic positioning of women and, I would argue, the discourses which uphold our structural subordination to men. This chapter and the following one are an acknowledgment that these varying positionings are sustained and perpetuated in the complex interplays at various sites, between the discourses of gender, ethnicity and class.

This chapter, further, acknowledges the one major event which has happened in 1993, the publication by the Ministry of Education of Sturrock's report The Status of Girls and Women in New Zealand Education and Training (Sturrock, 1993) which sets out very clearly the existing differences in educational trajectories, achievements and subsequent labour market participation between men and women. Such differences have their locus in the complex interplay between subjectivity (being feminine) and structural subordination (being a member of a non-dominant group in a hegemonic system $)^{3}$, which the market model cannot acknowledge or account for. When these differences are analysed and linked to the other realities of many women's lives, the market model, which has guided educational policy and practice, is found to be even more wanting. For example, this discussion acknowledges "realities" which are for girls and women closely related to their experience of the education system. These include changing family structures. Many children grow up in one parent families, headed by women, which exist on state benefits. The benefits were slashed in 1991. This is a situation not only with enormous social and economic implications for such people, but with serious educational ones as well. New Zealand has the highest fertility rate for 15-19 year olds in the world. We also have very high numbers of our young women who smoke, which has serious lifestyle implications for them and their children. All of these "realities" should be acknowledged and integrated into current educational policies, planning and the allocation of resources. The hegemonic models which have guided educational restructuring and current policy foci cannot do this. Their background assumptions do not allow them to, nor do their theoretical tools.

\section{The Theoretical Basis of Public Sector Restructuring}

Public choice theory, agency theory, transaction cost analysis and new public management theory all embrace the legitimacy of the free market as the mechanism through which meaningful and mutually beneficial personal interactions and transactions take place. All embody a commitment to methodological individualism and the sanctity of self interested individuals who are "rational utility maximisers of all their behavioural/personal capacities" (Boston, 1991, p.2). These theories have not only been central to the articulation of neo-liberal political discourse (O'Neill, 1993), they have contributed to changes in policy making processes, the issues they are concerned with and the way these are analysed and understood. They are thus central to the translation of policy into action, and have, in effect, touched and shaped the lives of all of us as state constituents.

Public choice theorists openly reject concepts like the "public interest" or "social justice", believing that individuals acting in their own interests in the economic market place will naturally secure such outcomes. Agency theory completely ignores the power and authority dynamics underlying human relationships, institutions and the structural basis of capitalist relations. While its application in the New Zealand context underlying, for instance, the Employment Contracts Act, has been modified, it assumes an equality (and resource base) between people that can 
never account for the salience of class, gender or ethnic positionings. Management theories and more broadly managerial ideologies (Evans and Davies, 1990, p.55) have perpetuated the assumption that policy decisions made in the context of a quasiprivatised environment will be more "rational" and hence more effective because they are more attuned to the demands of the market. So called "neutral" mechanisms are assumed to be able to be applied by people, who do not have vested interests in the policy outcomes. These theories are unable to acknowledge the complexity of the state as a relational institution which must facilitate a multitude of competing demands essential to its own survival and legitimacy, as well as that of the capitalist market place. Many of the inter-relationships the state must sustain are conflicting and not quantifiable as straight-line accountability mechanisms. Indeed many of its functions are beyond economic quantification and the application of profit maximisation incentives. Of course it should be acknowledged that while management theories enable the adherence to free market monetarist ideals, they do not necessarily imply the total destruction of the welfare state. But at their core is a drive for efficiency and accountability thought automatically to reside in the processes of the private sector, as opposed to the politically and economically indulgent realm of the public. The model of the individual thought necessary to facilitate such efficiencies is thus that of rational-market-man. The quest for efficiency and accountability has meant that:

the policy agenda has been dominated in recent years by issues relating to the design of incentive structures and contracts, the analysis of alternative governance structures, the avoidance of interest-group capture and bureaucratic capture, the pursuit of contestability and external contracting, the application of agent-principal models to a variety of relationships, the minimisation of transaction costs and agency costs, and the specification of outputs and outcomes. (Boston, 1991, p.23)

Indeed, many of the chapters in the New Zealand Annual Review of Education 2:1992 discussed the educational outcomes of policy agendas driven by these theoretical models. Boston has warned that the hegemonic dominance these frameworks have attained in the management of our public institutions could tend to blind policy makers to the:

insights of earlier political philosophies, administrative traditions and organisational theories, or lead them to ignore the way public agencies have been shaped by the forces of culture and history (ibid).

For Boston what is needed is a sense of history and the maintenance of a "theoretical pluralism" (ibid). This may be so, but it rather underscores the total co-option of the meanings of freedom, choice, flexibility, accountability, empowerment and community into the New Right agenda. As feminist analyses of these reforms have revealed these discourses are integral to the workings of the libertarian marketplace as are the assumptions of possessive individualism and the model of rational-market-man (Middleton, 1990; Bunkle and Lynch, 1992).

These analyses also point out that the partial dismantling of the welfare state, like its continued existence, has been done on the backs of women's labour and on the backs of their continued structural subordination to men. As I have argued (O'Neill, 1993), the welfare state was certainly open to rigorous criticism for its oppressive gender discourses. However, as it is pushed away out of peoples' lives, women are even worse off, as Bunkle and Lynch argue:

The assumptions and effects of the free market ethic serve the needs of those who can command power and financial resources; in New Zealand this group is predominantly white, middle class, middle-aged, able-bodied and male. Traditionally, women in New Zealand have been confined to lower-paid employment, had little access to credit, and have been over-represented as social welfare beneficiaries. The effects of this past discrimination are now being exacerbated by the free market economy which continues to undervalue women's work (1992, p.23). 
Thus the social and economic policy agenda and the restructuring of our education system have been underlaid by these hegemonic intellectual currents. Of course they have not been the only significant influences. For example, the principles of the Treaty of Waitangi and the presence of various equity agendas must be acknowledged. But the theoretical assumptions I have discussed, and a further accompanying and interlinking armoury of social and economic concepts, have guided restructuring and policy since the fourth Labour Government took office. As Bunkle and Lynch argue, such policy assumptions only account for the "realities" of a certain privileged group of people in our society. We now have a substantial body of literature to draw upon to verify that this is the case. The literature, much of which is published by state agencies, shows that many people live lives which are very different from that of the model embodied in rational-market-man. After discussing some of the major findings of Sturrock's report, the data is referred to in order to acknowledge the other "realities", to single out their importance in the setting of broader educational policy agendas and directions and to indicate that acknowledgment of them invalidates market models.

\section{Report: The Status of Girls and Women in New Zealand Education and Training}

By far the most exciting development to have happened for girls and women in education in 1993 was the publication of the Report written by Fiona Sturrock for the Ministry of Education. It is clear that this text, which was to have been published in 1992 has now been published with the political intent of diffusing some of the negative publicity surrounding the disestablishment of the Girls' and Women's Section in the Ministry.

Nevertheless, it is a very important document and the Ministry is to be congratulated on its publication. It represents a departure from older style state policy discourse, in that it actually engages with local academic analyses. This, combined with the statistical database the Ministry have always kept, means it makes for very expansive reading which will be accessible to a wide range of parents, students, practitioners and policy makers. Sturrock gets down to basics immediately in the first part of her introduction by acknowledging the importance of egalitarian ideologies to our understanding of social processes in New Zealand. She also makes the point that we know about inequalities in the secondary and tertiary sectors because of the availability of Ministry data. The early childhood and primary areas are harder to quantify and, therefore, to monitor and assess (pp.13-14). Ethnicity is also acknowledged early on in terms of "those of Maori and Pacific Islands ethnicity (being) doubly disadvantaged" (p.14). Further on this is qualified by the comment:

there has been little systematic treatment of the interactive effects of ethnicity and gender in the analysis of educational equity. Therefore, wherever possible, information on the position of Maori and Pacific Island girls and women is described and compared with their cohorts of other ethnic origins. These analyses are critical to our understanding of gender issues in education because they make visible those girls and women whose educational experiences do not mirror national trends (ibid).

Sturrock also argues for the need to acknowledge those who are differently abled in our system. She cites Neale's (1984) work which noted a tendency for these female students to take "soft" subject options, while expecting that they would spend less time at school than their non-disabled cohorts. Sturrock argues that "the combination of these two factors made the former the most disadvantaged group as far as opportunities for further education and training and variety of career options were concerned" (p.15). The monitoring and interpreting of data on such groups is complex. The ratio of males to females in full-time special education facilities is two to one. Sturrock suggests this could be related to the measures of identification used, or a function of the presenting symptoms. For example, boys' behavioural problems 
tend to be outwardly directed whereas girls usually present more passively. The Report goes no further than this to account for the differently abled. However, it is the first time I have ever seen such overt reference to these groups included in local work on gender and education. We need far more basic information on the visually and aurally impaired in our system as well as those with other physical, intellectual or behavioural difficulties to be integrated into mainstream educational analyses. Sociological analyses will never start to integrate an acknowledgment that such groups even exist and that they all have particular needs and experiences of our system, unless basic information is made more readily available and used.

Using 1990 and 1991 data obtained from three main sources, the Report has chapters on the early years of education ${ }^{4}$, secondary school, post-secondary education and training, women in the labour force and a final discussion chapter. The following section sets out some of the key findings of the Report.

\section{Selected Themes in Relation to Women and Education}

\section{Female Retention}

Historically, young women have been less likely to be retained in the sixth and seventh forms than their male peers. Over the past two decades this trend has reversed. This is an indicator that more young women and their families now see the value of advanced educational qualifications. It indicates changes to the entry criteria for teaching and nursing (which still absorb a significant number of female school leavers) and it indicates the pressure that labour market realities place on girls whose options are severely restricted without sixth form qualifications.

The percentages of total female retention in form sixincreased from $39.7 \%$ in 1970 to $80 \%$ in 1991 (compared with males: $74.6 \%$ in 1990). Since 1980, the number of Maori women entering this form has doubled. Female form seven retention increased from $8 \%$ in 1970 to $42 \%$ in 1991 (Sturrock, 1993, p.29). For every 100 Maori women who entered secondary school in 1987, six had left before the middle of their fourth form year and a further ten left before the middle of the fifth form. Thus, one sixth of young Maori women from this cohort did not remain at school past the compulsory age of 15 years. This compares with one-twentieth of their non-Maori classmates. In 1991, 35\% of Maori, 15\% of nonMaori and $22 \%$ of Pacific Island girls left with no qualifications. In that same year $15 \%$ of Maori, $42 \%$ of non-Maori and $26 \%$ of Pacific Island girls attained seventh form awards. There have been clear improvements in the attainments of Maori females, but the differential between Maori and non-Maori still remains because non-Maori rates have increased also (ibid, p.33).

\section{Subject Choices}

At the junior secondary level marked gender differences in participation in the ideologically designated "soft" female subjects and "hard" male subjects are apparent (see O'Neill, 1990 for a discussion of the ideological tagging). This trend is exacerbated as women continue on to the senior levels. Of the total female third form enrolments in optional subjects for third formers in 1991, $85 \%$ took Languages (compared with $62 \%$ of the males), $46 \%$ took Typing (20.5\% male), $44 \%$ took Home Economics (26\% male), $22 \%$ took Craft/Technological Design (20\% male), $8 \%$ took Keyboard Skills, $4 \%$ took Woodwork, and 2\% took Engineering (Sturrock, p.35). In 1990, females constituted $1.9 \%$ of School Certificate Engineering students, 13\% of Technical Drawing, 48\% of Accounting (42\% at Bursary level), $49 \%$ of Geography $(51 \%$ at Bursary), 58\% of History (59\% at Bursary), 59\% of Maori (58\% at Bursary), $78 \%$ of Home Economics, and 96\% of Typing enrolments (ibid, p.37). This ideological tagging of subjects as masculine and feminine continues on into tertiary level and manifests itself in the structuring of the labour market.

In the 1991 internal university enrolment in selected undergraduate programmes, women constituted $85 \%$ of Social Work students (80\% in 1981), $80 \%$ of Education $(80 \%$ in 1981), $57 \%$ of Veterinary Science (36\% in 1981), 55\% of Law (30\% in 1981 ), $50 \%$ of Medicine (30\% in 1981), $40 \%$ of Technology (30\% in 1981 ), and $10 \%$ of Engineering (5\% in 1981)(ibid, pp.74-75). 
The Report provides detailed discussion on trends in subject choices at the secondary level. Most importantly it includes ethnic breakdowns in performance differences, gender differences in subject combinations and in subject participation in relation to school type. In both Mathematics and Science, there are almost equal proportions of male and female students at School Certificate levels. At the higher levels there are noticeable splits. At Bursary, men markedly outnumber women in Mathematics with Calculus and Mathematics with Statistics. At Sixth Form Certificate level, Biology is more popular with women and Physics is chosen by more men. In Chemistry the proportions are equal at this level. This pattern is repeated at the Bursary stage for Biology and Physics and men also predominate in Chemistry at this level (ibid, p.44). Numbers are equal at all levels of Geography, but women constitute greater numbers of History students at all levels. At the higher levels of Economics male numbers increase. Males predominate in Technical Drawing and Engineering and females dominate Typing, Home Economics and Art. Secondary level performance differences are also analysed in terms of ethnicity.

Chapter Four provides an overview of Women in PostSecondary Education and Training. As a result of the increased retention rates of women into senior secondary education (and, I would add, changes in the gendered strategies of family reproduction processes, credential inflation and unemployment), female participation in the tertiary sector in New Zealand has improved so that the numbers of women students at polytechnics are approaching those of men, and female enrolments in universities now outnumber male (ibid, p 64).

\section{Labour Market Participation}

Chapter Five, Women in the Labour Force, highlights emerging trends for female workers and makes links to the educational system while indicating trends for it to heed. It shows that there is a disproportionate number of women employed part-time in that they make up $73 \%$ of that workforce. One woman in three is employed for fewer than 30 hours per week while the corresponding figure for men is one in ten (ibid, p.97). In 1961 women made up $16 \%$ of professional/technical occupations, in 1991 it was $27 \%$. For administrative/managerial occupations it was $1.9 \%$ in 1961, and $8 \%$ in 1991. For clerical workers it was $28 \%$ in 1961 and $26 \%$ in 1991. In sales and service it was $28 \%$ in 1961 and $19 \%$ in 1991. One of the most interesting and useful tables in this section which is not readily available elsewhere is that which sets out the disparity of the average incomes (for 1981 and 1986) for men and women working in a large number of occupations. For example, in 1986 the average income of women primary teachers was $\$ 20,152$ and $\$ 24,543$ for men. For secondary teachers it was $\$ 22,852$ for women and $\$ 26,497$ for men. For university lecturers it was $\$ 24,084$ for women and $\$ 34,762$ for men. For electricians it was $\$ 12,094$ for women and $\$ 20,237$ for men. For doctors it was $\$ 29,385$ for women and $\$ 39,585$ for men. For Ministers of Religion it was $\$ 9,373$ for women and $\$ 15,018$ for men. For plumbers it was $\$ 12,955$ for women and $\$ 18,393$ for men. For personnel officers it was $\$ 20,785$ for women and $\$ 27,520$ for men. For secretaries/assistants it was $\$ 18,877$ for women and $\$ 25,532$ for men. Out of the twenty-six selected occupations for 1986, only two, pre-primary teachers and members of parliament, had a slightly higher female average wage. In 1981 men earned approximately two-thirds more than women, and one-third more in 1986. Interestingly the gender differential has been reduced in all occupations except those of university lecturers and electricians.

In $1987,9.7 \%$ of women (10.9\% male) in the $15-19$ year-old age group were officially registered as unemployed. In 1992 the figures were $19.5 \%$ for women (24\% for men). The 1987 figures for the $20-24$ year old age group were $5.6 \%$ for women (7\% for men) and in 1992 this was $11 \%$ for women (17\% for male). Sturrock points out that the 1991 Labour Force Survey found that more women than men were discouraged workers, that is, persons who had given up the search for work because they perceived their 
prospects of employment to be poor. She acknowledges that these people become hidden unemployed, since official unemployment rates include only those actively seeking employment. While Sturrock also mentions under-employment in relation to women, there are important omissions in the discussion here. The Department of Statistics figures that are used, are calculated on the basis of the category of employed ridiculously including anyone who is in paid work for one hour a week (O'Neill, 1993). It should be noted that the additional retention of young people at secondary school, the age barrier to the receipt of the unemployment benefit and the stand-down period before certain groups are able to receive the benefit, are factors that all work to skew the official figures and keep them considerably lower than they are.

\section{One Parent Families}

As I argued last year (O'Neill, 1993) the model of the rationalmarket-man which underpins free market models never openly acknowledges the existence of the traditional nuclear family (and the dependency relationships it involves). Indeed, women are characterised as irrational to withdraw from the labour market and the benefits participation in it brings, and retreat into the home (not perceived of as a site of work). Market models implicitly assume the legitimacy of this traditionally gendered structure. And as the Treasury Briefing Papers (NZ Treasury, 1987) made clear, it is necessary to the market; certain things are learnt and provided within its context - it is just never thought necessary to acknowledge these, theoretically or economically.

Further, the market model cannot acknowledge the reality of changing family structures in New Zealand. People are living in increasingly different ways. By 1991 a quarter of all families with children were one parent families (108,435 as compared with 70,000 in 1976 and 89,960 in 1981). At this time $3 \%$ of these families were headed by teenagers, with sole mothers outnumbering sole fathers by a ratio of 5:1. Broken down, the figures show that $44 \%$ of all Maori, 32\% of all Pacific Island and 18\% of all European families with children were one parent families (Rochford, 1993, p. ix). As a proportion of total families with children, sole parent families have increased from $10 \%$ in 1976 to $13 \%$ in 1981, 18\% in 1986 and 24\% in 1991 (Sturrock, p.10). By 1991,16\% of sole parents were male (one in every six). Single families living with other people or family units have become slightly more common, and there are more situations now where two or more families live together. The traditional two-child family has been overtaken by the one-child as the most common type of household. In 1991, $36.3 \%$ of our families with children had two children, while $39 \%$ had one (Public Health Commission, 1993, p.56). The Public Health Commission sees this change as one of the last decade's most important social trends which, it argues, has resulted from increased separation and divorce and decisions to bear children but not to marry or live together (ibid, p.57).

About half (51\%) of sole parents of European ethnicity, two thirds (69\%) of Maori, and over two thirds $(70 \%)$ of Pacific Island sole parents were not in the labour force and not seeking work. Thirty-eight percent of European sole parent families were in paid employment (full and part time), $29 \%$ of those being in professional/technical and $20 \%$ being in clerical occupations. Thirty-two percent of this total group were in part-time work while 68\% were in full-time (Rochford, 1993, p.22). Seventeen percent of Maori sole parent families were in paid employment, $19 \%$ of those being professional/technical, $17 \%$ in clerical and $20 \%$ were trades, plant or machine workers. Twenty-two percent of this total group were in part-time work while $78 \%$ were in fulltime (ibid, pp.22 \& 58). Twenty percent of Pacific Island sole parent families were in paid employment, $27 \%$ were trades, plant or machine workers and $20 \%$ were in clerical. Twenty percent were in part-time work while $80 \%$ were working full-time. Overall only 33\% of sole parents in 1991 were employed, whereas in two-parent families $88 \%$ had at least one parent working, and $54 \%$ had both parents working (Public Health Commission, 1993, p.57). 
Forty percent of European, 66\% of Maori and 59\% of Pacific Island sole parents had no educational qualifications (ibid, p. 54). Both the Public Health Commission's Report and the Social Environment Scan (1993) which is part of the Briefing Papers prepared for the incoming Minister of Social Welfare in 1993, highlight the fact that sole parents and, by implication, their families, when compared to partnered parents, exhibit characteristics of disadvantage in terms of employment, income, education and housing tenure. Within this population Maori appear to be the most disadvantaged. For example, 65\% of European, $72 \%$ of Maori and $57 \%$ of Pacific Islands sole parent families received their income support from the Domestic Purposes Benefit. Eighty-eight percent of all Maori sole parent families are supported by income-tested benefits and 38\% of all Maori families with children are headed by sole parent beneficiaries (Rochford, 1993, p.34). Maori sole parents who were employed were more likely to be working full-time than European sole parents, had a higher proportion actively seeking work than the other groups and were less likely to be in professional jobs and more likely to be in production/transport occupations (ibid). The median annual income of one-parent families in 1991 was $\$ 15,900$ compared with $\$ 45,000$ for twoparent families.

When this structural breakdown is placed in the context of the results of National's December 1990 package (the April 1991 benefit cuts) which reduced income support for most beneficiaries with families and tightened eligibility criteria for all groups, it represents what is, for many, an existence characterised by hardship, uncertainty and, increasingly, poverty. The April 1991 cuts to all welfare benefit levels averaged out at $\$ 25$ per week (Stephens, 1992, p.109). More specifically, the unemployment benefit for a single person aged between 18-19 years went from $\$ 114.86$ in March to \$108.17 in April 1991. For those over 25 years it was reduced from $\$ 143.57$ to $\$ 129.81$. For a single person with one child it was reduced from $\$ 255.14$ to $\$ 227.93$. The widows and domestic purposes benefits were reduced from $\$ 255.14$ for a single person with one child to $\$ 227.93$. For someone with two children it went from $\$ 292.82$ to $\$ 266.83$.

Waldergrave and Frater (1991) calculated that these cuts affected the disposable income of childless beneficiaries by about $\$ 1,200$ per annum. This signified $10 \%$ of disposable income for a married couple and $16 \%$ for a single person. Losses for those with children were roughly $\$ 2500$, increasing with family size and amounted to what they saw as roughly $15 \%$ of disposable income. For a two-parent, three-children beneficiary family the loss was $\$ 4,575,26.6 \%$ of their disposable income (ibid).

Easton (op cit, 1993, p.13) has calculated that the total impact of this package, including eligibility criteria and user charges, was to cut the material standard of living of the poorest (beneficiary) households by just over $21 \%$. The average loss for low income earner non-beneficiaries was about $15 \%$, compared to that of $3 \%$ for high income earners (Stephens, 1992, p.114). Easton (1993) argues that based on the poverty line measure set by the 1972 Royal Commission on Social Security which uses the "Benefit Datum Level" (the rate set as suitable for a couple on a benefit, adjusted to 1993) the cut for a married couple's unemployment benefit means that the level is 18\% lower than the rate recommended in 1971. According to this measure, one Easton calls a very modest indicator of poverty, there were about a third of a million people living in poverty in 1989/90. This had risen to half a million in 1993. Hence, during this time an extra 150,000 people's incomes fell below the poverty line in that time. This is a rise of over $40 \%$ between 1990 and 1993. If the 1972 Commission's figures are adjusted for the $12 \%$ growth in incomes over that period, the poverty figures are even worse (ibid, pp.9$10)$. The modest poverty level means that just over $10 \%$ of the population were living below the poverty threshold in 1989/90, and around 15\% were living in poverty in 1991/92. As Easton points out, most of these people were children and their parents. 


\section{Adolescent Sexuality}

Compared with other western countries New Zealand has a relatively high rate of live births to adolescent/teenage mothers. This fertility rate (the live birth rate per 1,000 women) is due to the influence of many factors including our attitudes to the availability of contraceptives, the refusal of many parents and schools to discuss sexuality and sexual practices, relatively low abortion rates, and of course hegemonic conceptions of masculinity and femininity and the appropriate conception of the expression of sexuality embodied in these.

In 1992 the New Zealand Family Planning Association initiated a "Changing the Message" campaign which aimed at encouraging responsible attitudes towards sexuality. It challenged the double standard of our news media in relation to explicit portrayals of sexuality and what it sees as an acute lack of honest, specific information for young people. Family Planning also emphasised that the gender issues around sexuality needed to be opened up for debate and contestation, particularly the "machoness" so inherent in our understandings of masculinity.

Table 1 Fertility Rates of New Zealand Women

\begin{tabular}{lrrrrrrrr}
\hline $\begin{array}{l}\text { Rate (live births per } \\
\mathbf{1 0 0 0} \text { (women) }\end{array}$ & $\mathbf{1 9 7 1}$ & $\mathbf{1 9 7 6}$ & $\mathbf{1 9 8 0}$ & $\mathbf{1 9 8 3}$ & $\mathbf{1 9 8 6}$ & $\mathbf{1 9 8 8}$ & $\mathbf{1 9 9 0}$ & $\mathbf{1 9 9 2}$ \\
\hline 15-19 years & 68.0 & 51.0 & 38.5 & 32.4 & 36.0 & 37.0 & 34.0 & 33.6 \\
Under 16 years & 3.7 & 2.6 & 2.0 & 2.0 & 0.2 & 0.5 & & \\
\hline
\end{tabular}

Overall, the fertility rate for 15-19 year-olds has declined in New Zealand so that in the late 1980s it was around half what it was in the early 1970s. In 1986 our rate, at 36.0, was higher than that of Australia at 21.0, Canada at 23.0, and England and Wales at 31.0. It was also higher than that of Denmark, France, Norway, Scotland, Sweden and Germany (Maskill, 1991, p.53). In 1988 at 37.0 it remained higher than Australia (20.2), Canada (23.2), England and Wales (32.4), and Scotland (30.8) (Department of Health, 1992, p.15). In 1992 at 33.6, the New Zealand figure remained higher than all the other countries we are normally compared with (Public Health Commission, 1992, p.15).

For Maori women the rate has steadily declined but is still double that of the total population. It went from 130 (live births per 1000) in 1971 to 120 in 1975, 99 in 1981, 90 in 1984, 83 in 1986, to 80 in 1988 and 78.8 in 1990 (Maskill, 1991, p.53). Our high fertility rates must also be read in tandem with our teenage abortion rates which are lower than those for many other low fertility countries. Overall, abortion rates have risen for all ages during the last ten years, especially since 1985 . For the $15-19$ year old age group they have gone from 12.5 per 1,000 women in 1981, to eleven in 1984, 16 in 1990 and 17 in 1991. It is important to note that this rate has increased the least out of all the age groups. There are ethnic differences in induced abortion rates for adolescents also. Maori and Pacific Island women under 20 years have significantly higher rates than other ethnic groups. For example in 1986, the rates were 12.2 for "European and other", 15.4 for Maori and 24.2 for Pacific Islanders (ibid, p.55).

In a large national survey of New Zealand abortion patients in 1983, Maori and Pacific Island women were significantly overrepresented among non-users of contraception (Sceats, 1988). Sceats argued that this suggests inadequate access to knowledge and methods of contraception. The higher abortion rate for Pacific Islanders follows a similar pattern found amongst immigrant groups in the United States and the Netherlands.

Much of the New Zealand research into sexual behaviour among adolescents has varied in its methodological approach, the age of the population studied and ways in which sexual activity has been defined. However, despite these variations, it is clear that a significant proportion of adolescents are sexually active. The estimates are between $30-40 \%$ of girls and $40-60 \%$ of boys. In the overview of this literature, boys are found to have earlier sexual experiences and more partners, while girls tend to be active within the context of a relationship (Maskill, 1991, p.47). Maskill (ibid) also points out that early school leavers tend to have 
earlier sexual experiences, and that this is likely to be associated with lower educational and economic status. The literature indicates that young Maori men and women experience sex at earlier ages than their Pakeha counterparts, which suggests that there may be cultural differences in the acceptability of sexual behaviour in adolescents. Maskill (ibid) warns, however, that studies have not been set up in ways which allow careful study of this, therefore further investigation is necessary to gain reliable information.

McEwan et al.'s (1988) survey of a sample of 162 form six and seven students aged 16-19 in an urban co-educational high school, found that $44 \%$ of males and $37 \%$ of females reported sexual activity. Overall, $22 \%$ of all students (55\% of those reporting sexual activity) indicated that their first intercourse was before 16 years of age. No significant differences were found between male and female at age of first intercourse, or in numbers of partners. Gender differences were revealed in the nature of sexual relationships, with females reporting a higher proportion (47\%) of "steady" relationships than males (19\%), and males reporting a higher proportion of "casual" sexual partners (48\%) than young women $(20 \%)$.

Brander's (1991) study of a sample of 231 sexually experienced $15-19$ year olds who presented at Family Planning and STD clinics in Christchurch in 1989, found that $95 \%$ had experienced sexual intercourse and that more than half $(55 \%)$ of those aged 19 and under, had their first sexual experience before 16. Although this sample could not be considered to be representative of all New Zealand adolescents, the finding is comparable to McEwan et al.'s. Brander also found that most of the sample (75\%) had more than one partner (a higher level than that reported by McEwan et al.), which probably reflected STD clinics, as the source of part of the sample. This survey reported a very low incidence of homosexual and bisexual experience, which she also relates to the drawing of the sample from services offering contraceptive supply and advice.
72 Anne-Marie O'Neill

Brander's study demonstrates a relatively high level of risk practices amongst the adolescent groups currently using services which aim to prevent adverse consequences of sexual activity. Of the 231 adolescents surveyed. $80 \%$ were female, just over half were still at school or studying elsewhere, and over two thirds were living at home. Just over one third of the sexually experienced group used no contraception at first intercourse. Almost three quarters of the group who did not use contraception at first intercourse were under 16 years at the time. Less than half the group reported "always currently using contraception" and $10 \%$ of those surveyed reported "never using any contraceptive method". Those individuals considered to have the safest sexual practice (i.e., "always use condoms") were almost twice as likely to have used protection at first intercourse as the remaining group. Brander argues that an educational focus which promotes the use of contraception at first intercourse may be an effective means of reducing adverse outcomes associated with sexual activity (such as sexually transmitted diseases and unplanned pregnancy). A high level of interest was expressed by the sample in attending a Family Planning Association clinic only for people under 20 years and offering services and information concerned with contraception and sexual health. Brander argues that such centres should be considered in future evaluations of effective health promotion methods and venues.

Brander concludes that the results from this survey endorse repeated calls from previous researchers (Barns and Maxwell, 1980; Cameron, 1988; McEwan et al., 1988; Page et al., 1975) for improved contraceptive knowledge and accessibility as the most effective means of reducing the incidence of unintentional pregnancy and sexually transmitted diseases within the adolescent population.

\section{Smoking}

Increased interest in the smoking behaviour and attitudes of young people is partly the result of concern about high smoking 
prevalence, especially of this group and particularly of young women. The total cost of cigarette smoking to health services alone is estimated to have been \$202 million in 1992 (Public Health Commission, 1993, p.125). A breakdown of Census data for the years 1976 and 1981 showed that the smoking prevalence among 15 to 19 year-old males had declined from $30 \%$ to $27 \%$, while the rate for females remained static at 30\%. In 1981 the highest rates were among the 20 to 24 age group (40\% for both men and women). It was also found that a very high proportion $(70 \%)$ of young Maori women in this age group were smokers. These figures contrast sharply with the decline in smoking prevalence among older groups (McClellan, 1987, p.1).

By 1991 a quarter of the adult population were smokers. In that year smoking was most common among males aged 25 to 34 years $(35 \%)$ and it was second highest among females aged 15 to 24 years (33\%). In both 1981 and 1991, the proportion of women smoking was higher than men only in the 15 to 24 year age group. In 1981 Maori women in that age group had the highest rates of all smokers at $64 \%$ (men were 56\%) (Public Health Commission, 1993, p.128). Between 1981 and 1991, the proportion of people smoking decreased across all age groups. Women in the 15 to 24 age group, however, had the lowest decrease, with only $3 \%$. Census data from 1981 shows that for people aged over 15 years, $53.5 \%$ of Maori males and $58.5 \%$ of Maori females (compared with $33.1 \%$ of non-Maori males and $27.3 \%$ of non-Maori females) were regular smokers.

Of the 2,252 form one students included in McClellan's (1987) survey, $9.5 \%$ were current smokers. Just over $90.5 \%$ had either never smoked or were not current smokers. Girls more commonly than boys reported having never smoked a cigarette. However, the differences in the smoking behaviour patterns of males and females were generally not significant. There were clear differences between the smoking behaviour of Maori students and that of the three other ethnic groups surveyed in this study. When compared with their Pakeha counterparts, Maori students were more likely to have smoked (54\% compared with $37 \%$ ), and were twice as likely to be current smokers (16\% compared with $8 \%$ ). The classroom discussions which took place in this survey revealed that the myth that smoking makes you slim was widely held to be true for form one students. Unfortunately the survey was unable to ascertain whether different frequencies for holding this belief existed between boys and girls. Bonita (1983) and Sadgrove (1985) argue that this belief may be female specific.

It is well known that adolescent girls and young women come under enormous pressures to fit the ideals of slimness that the electronic media, magazines, the fashion industry and their peers press upon them. Feminist and medical researchers suggest that these pressures, added to the personal vulnerability inherent in membership of a subordinate social group, mean that young women are particularly susceptible to advertising and peer pressures in relation to smoking. The dangers for women who smoke are important for those who are sexually active, and those who want to have children, as are the incidences of smoking related diseases for Maori women.

\section{Suicide}

The New Zealand male and female suicide rates for those aged 15 to 24 years rank among the highest in the OECD and exceed those in Australia, the United States and the United Kingdom. Male rates exceed those of females: 40 per 100,000 in 1990 for nonMaori (20 in 1980), and 31 for Maori males (7 in 1980). For nonMaori females it was 8 per 100,000 in 1990 (7 in 1980) and 3 for Maori (5 in 1980). Both Maori and non-Maori rates of hospitalisation for intentional self injury are higher for females than males and increased from 1981 to 1988 and 1990 to 1991 (Public Health Commission, 1993, p.211).

\section{Conclusion}

This chapter can only really provide a small glimpse into the collective pictures of women's lives, that are, in reality, multidimensional. These glimpses have been opened up in order to 
signal the need to broaden the areas of analysis for the sociology of education and the "sociology of women's education". They also signal the intellectual paucity of market models that cannot even acknowledge that women's lives are lived out differently, let alone the huge variations in positioning and experience within that difference. They make very clear that in any consideration of education and differential attainment (the gendered nature of which has been discussed (Sturrock, 1993)), resources must be seen to be paramount. As this chapter has shown, there are now huge sectors of our population where the few resources women did have, have been depleted even further, a fact that must be understood in the context of the disparity between male and female hourly and weekly earnings and the fact that women have fared worse under the Employment Contracts Act (Foulkes, 1993, p.11). Women are more than twice as likely as men to work parttime and half as likely to work full-time. In September 1991,17.9\% of the female labour force was in part-time work, whereas only $6.6 \%$ of the male labour force was in part-time work (Broadsheet, 1993, p.33). In March of 1992, part-time work accounted for more than a fifth of all employment. Women made up 73\% of that workforce and the number of employed women who work parttime had risen to 36\% (Foulkes, 1993, p.11). As the discussion of sole parents and fertility rates has shown, there are disparities between ethnic groups notably in relation to unemployment. The rate in 1991 was 6.9\% for Pakeha women, for Maori it was 25.6\%, for Pacific Island women it was $29.2 \%$ and for those with disabilities it was an estimated 37.6\%. In 1992 women carried out approximately $\$ 22$ billion worth of unpaid work. Women perform two thirds of all unpaid work, which is estimated to account for between 30-58\% of the Gross Domestic Product (Broadsheet, 1993, p.33).

There are differences between the genders in every aspect of social and economic life that they both participate in. There are vast differences within the categories of "male" and "female" themselves. As the quote from Hewlett stated at the beginning of this chapter, and as this discussion has demonstrated, our deterioration in living standards has been particularly severe among families with children - but this has hit some families more than others, and some women more than others. We desperately need social and educational policies which can take account of structural disparities between population groups, which can account for the feminisation of poverty and which can dislodge themselves from adherence to the contextually blind model of rational-market-man. The model is a fiction and until it is abandoned, educational policy will never acknowledge the real ways in which women live.

\section{Notes}

1. Sharp and Broomhill (1988) pose three questions for feminist analyses which I believe all analyses of the state must consider:

- What role does the State play in either causing or at least maintaining the subordinate position of women?

- To the extent that the State does participate in the subordination of women, for what reason and in whose interests does it act? Is it primarily capitalism or patriarchy?

- Are there aspects of State policy which benefit women and reduce social inequalities? How can women harness the State and its policies to improve their position?

2. This was according to Dr Gareth Morgan and was a figure given to include hidden unemployment on Prime Time News, TV One, on 30 June, 1993.

3. Hegemonic means it is a constituitive part of the dominant belief system and way of looking at the world. Hegemonic world views are perpetuated and disseminated through the discourses of those who have power and influence in a society like ours: the ruling classes.

4. Detailed demographic information is not collected on children in early childhood. This chapter is a literature review. 


\section{References}

Barnes, M. and Maxwell, G. "Obtaining Contraceptives", in New Zealand Journal of Family Planning, 4-8, 1980.

Bonita, R. "Where There's Smoke, There's Fire", in Broadsheet, January/ February, pp.38-39, 1983.

Boston, J. "The Theoretical Underpinnings of Public Sector Restructuring in New Zealand"; in Boston, J. et al. (eds) Reshaping the State: New Zealand's Bureaucratic Revolution, Auckland: Oxford University Press, 1991.

Boston, J. and Dalziel, P. (eds) The Decent Society? Auckland: Oxford University Press, 1992.

Brander, P. Adolescent Sexual Practices, Wellington: Department of Health, 1991.

Broadsheet, Summer, 1993.

Bunkle, P. and Lynch, J. "What's Wrong With the New Right?", in Briar, C. et al. (eds), Superwoman Where are You? Palmerston North: Dunmore Press, 1992.

Burton, C. Subordination: Feminism and Social Theory, Australia: George and Allen Unwin, 1985.

Cameron, J. "New Zealand Population - Issues and Concepts, University of Canterbury, Department of Sociology (unpublished paper), 1988.

Codd, J. A., Harker, R. K. and Nash, R. (eds) Political Issues in New Zealand Education, first edition, Palmerston North: Dunmore Press, 1985.

Cox, S. and James, B. "Introduction", in Cox, S. Public and Private Worlds, Wellington: Allen and Unwin, 1987.

Department of Education The Johnson Report, Wellington: Department of Education, 1977.

Department of Social Welfare Social Environment Scan, Wellington: Department of Social Welfare, 1993.

78 Anne-Marie O’Neill

Easton, B. "Poverty and Families Priority or Dietry?" Paper to the Issues for Families Workshop, October, 1993.

Foulkes, A. Women and the Economy. Notes for an Address by Angela Foulkes, Secretary, NZ Council of Trade Unions, 1993.

Grace, C. "Labour and Education: The Crisis and Settlements of Education Policy", in Holland, M. and Boston, J. (eds) The Fourth Labour Government: Politics and Policy in New Zealand (Second Edition), Auckland: Oxford University Press, 1990.

Helly, D. and Reverby, S. (eds) Gendered Domains: Rethinking Public and Private in Women's History, New York: Cornell University Press, 1992.

Hewlett, A. Child Neglect in Rich Nations, New York: United Nations Children's Fund, 1993.

James, B. and Saville-Smith, K. Gender, Culture and Power, Auckland: Oxford University Press, 1989.

Lauder, H. and Wylie, C. (eds) Towards Successful Schooling, London: Falmer Press, 1990.

Levitas, R. The Ideology of the New Right, Cambridge: Polity Press, 1986.

Maskill, C. A Health Profile of New Zealand Adolescents, Wellington: Department of Health, 1991.

McClellan, V. A National Survey of the Smoking Habits of Form One Students in New Zealand Schools, Wellington: Department of Health, 1987.

McCulloch, A. and Cleary, D. "Suffrage Year 'A Wake for a Tamed Movement" ", in The Dominion, December 8, 1993.

McEwan, B., Aukett, R. and Hills, M. D. "High School Students' Attitudes Towards and Use of Contraceptives", in New Zealand Medical Journal 101(842),1988, pp.142-145.

McKenzie, D. "The History of New Zealand Education", Research in Education in New Zealand: The State of the Art, NZARE/Delta Research Monograph 3, 1980. 
Middleton, S. "Women, Equality and Equity in Liberal Educational Policies 1945-1988", in Middleton S. et al. (eds), New Zealand Education Policy Today, Wellington: Allen and Unwin, 1990.

Middleton, S. et al. (eds) New Zealand Education Policy Today, Wellington: Allen and Unwin, 1990.

Neale, J. Where Next? Wellington: Further Education for the Disabled Group, 1984.

New Zealand Treasury Government Management, Volume II, Wellington: Education, 1987.

O'Neill, A-M. “The Equal Opportunity Myth", in Olsson, S. (ed) The Gender Factor: Women in New Zealand Organisations, Palmerston North: Dunmore Press, 1992.

O'Neill, A-M. "Policy Initiatives for Girls and Women in Education in 1992: Are We Included in the Decent Society?", in Manson, H. (ed) New Zealand Annual Review of Education, 2:1992, Wellington:

Department of Education, Victoria University of Wellington, 1993.

O'Connor, J. Accumulation Crisis, Oxford: Basil Blackwell, 1984.

O'Connor, J. The Fiscal Crisis of the State, New York: St Martins Press, 1973.

O'Neill, A. M. “The Gendered Curriculum: Home-Makers and Breadwinners", in McCulloch, G. (ed), The School Curriculum in New Zealand, Palmerston North: Dunmore Press, 1992.

Page, R., Werry, J. S. and Hutton, R. "Sexual Activity and Contraception Use in Young Adults", in New Zealand Medical Journal 82, 1975, pp.261-264

Pateman, C. The Disorder of Women, California: Stanford University Press, 1989.

Public Health Commission, Our Health Our Future. Hauora Pakari, Koiora Roa, The State of the Public Health in New Zealand 1993, Wellington: Public Health Commission, 1993.

Rochford, M. A Profile of Sole Parents From the 1991 Census, Wellington: Social Policy Agency Department of Social Welfare, 1993.
80 Anne-Marie O’Neill

Roper, B. and Rudd, C. (eds) State and Economy in New Zealand, Auckland: Oxford University Press, 1993.

Sadgrove, J. "I Deserve this Cigarette", in The New Statesman, 1985, pp.9-11.

Saville-Smith, K. "Women and the State", in Cox, S. (ed), Public and Private Worlds, Wellington: Allen and Unwin, 1987.

Sharpe, R. Knowledge Ideology and the Politics of Schooling: Towards a Marxist Analysis of Education, London: Routledge and Kegan Paul, 1980.

Sharpe, R. \& Broomehill, R. Short Changed: Women and Economic Policies, Sydney: Allen \& Unwin, 1988.

Stephens, B. "Budgeting With the Benefit Cuts", in Boston, J. and Dalziel, P. The Decent Society? Essays in Response to National's Economic and Social Policies, Auckland: Oxford University Press, 1992.

Sturrock, F. The Status of Girls and Women in New Zealand Education and Training, Wellington: Ministry of Education, 1993.

Theoborn, G. The Ideology of Power and the Power of Ideology, Great Britain: Verso, 1980.

Waldergrave, C. and Frater, P. (eds) "The National Government Budgets of the First Year in Office: A Social Assessment", Wellington: Business and Economic Research Ltd, 1991.

\section{The author}

Anne-Marie O'Neill is a Lecturer in the Education Department at Massey University where she has taught, inter alia, the Sociology of Women's Education, the Sociology of Education, curriculum theory and educational policy analysis. 